\title{
Solar disinfection modeling and post-irradiation response of Escherichia coli in wastewater
}

\author{
Stefanos Giannakis ${ }^{\mathrm{a}, \mathrm{b}, \mathrm{c}}$, Efthymios Darakas ${ }^{\mathrm{a}}$, Antoni Escalas-Cañellas ${ }^{\mathrm{b}, \mathrm{d}}$, César Pulgarin ${ }^{\mathrm{c}, *}$ \\ ${ }^{a}$ Laboratory of Environmental Engineering and Planning, Department of Civil Engineering, Aristotle University of Thessaloniki, 54124 Thessaloniki, Greece \\ ${ }^{\mathrm{b}}$ Laboratory of Control of Environmental Contamination, Institute of Textile Research and Industrial Cooperation of Terrassa (INTEXTER), Universitat Politècnica de Catalunya, \\ Colom 15, 08222 Terrassa, Catalonia, Spain \\ ${ }^{\mathrm{c}}$ Swiss Federal Institute of Technology, Lausanne, Institute of Chemical Sciences and Engineering, 1015 Lausanne, Switzerland \\ ${ }^{\mathrm{d}}$ Department of Chemical Engineering E Terrassa School of Engineering, Universitat Politècnica de Catalunya, Colom 1, 08222 Terrassa, Catalonia, Spain
}

\section{H I G H L I G H T S}

-We investigated the bacterial kinetics during and after simulated solar disinfection of secondary effluent.

- Production of 2 high accuracy models (shoulder log-linear and Weibull) was achieved.

- The dose for 4-log inactivation and the effective bacteriostatic dose (EBD) were found.

- Bacterial kinetics complied to light intensity and dose in reciprocal manner at close intensities.

- Long-term decay observed beyond the EBD, regardless of the irradiance applied.

\section{A R T I C L E I N F O}

\section{Article history:}

Received 18 March 2015

Received in revised form 16 May 2015

Accepted 17 June 2015

Available online 6 July 2015

\section{Keywords}

Solar energy

Disinfection

Regrowth

E. coli

Modeling

Intensity vs. dose
G R A P H I C A L A B S T R A C T

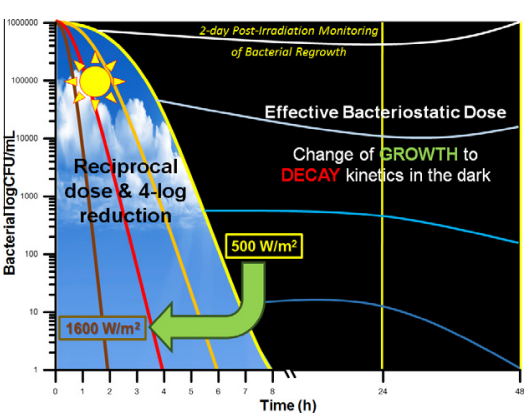

\begin{abstract}
A B S T R A C T
In this work, an intensive assessment of solar disinfection of secondary wastewater was elaborated in controlled laboratory conditions. Batch tests of Escherichia coli-spiked synthetic secondary effluent, at nine different constant intensity levels, were followed by a 48-h dark storage. Solar disinfection was monitored in half-hourly intervals demonstrating distinct phases of lag followed by sharp inactivation. The results were fit to a shoulder log-linear and a Weibull distribution model. The solar-driven inactivation, the latency period and the effective disinfection time (for 4-log reduction) were correlated properly with the applied irradiance, resulting in a common, standardized dose for all intensities. Evolution of bacterial response in the dark was monitored for $48 \mathrm{~h}$, and was in each case characterized as growth or decay. Also, the energy threshold, which was able to shift post-irradiation behavior from growth to decay, was analytically studied. In all intensity levels, this standard was approximately constant, as an effective bacteriostatic dose (EBD). Finally, similar dose-related disinfection and regrowth effects were observed, suggesting compliance with the reciprocity law, with minor deviations.
\end{abstract}

(c) 2015 Elsevier B.V. All rights reserved.

\footnotetext{
* Corresponding author. Tel.: +41 216934720; fax: +41216936161.

E-mail address: cesar.pulgarin@epfl.ch (C. Pulgarin).
}

\section{Introduction}

Although the disinfecting abilities of sun have been known for many years, it is only during the last few decades that this idea came to practice in the regions around the equator line [1]. The 
lack of proper sanitation conditions in these areas results in contamination of the natural water bodies that are used as drinking water supplies; rare and important water entities, such as rivers or wells are rendered inutile [2]. However, the coincidence of ample solar supplies in these areas favored studies on solar purification of drinking water sources [3-5]. A fair share of SODIS works, reviewed by McGuigan et al. [6] have demonstrated the ability of UVA and UVB wavelengths of the solar spectrum to inactivate a vast number of microorganisms, such as Escherichia coli, Salmonella, Shigella Flexneri, Fusarium and more [7-10]. Slowly, the interest has moved to wastewater treatment, and photolytic and photocatalytic methods have been used to target the present microorganisms [11-14].

Among researchers, the need to study and design applications of solar disinfection led to the modification of existing methods and models, in order to predict the outcome of the experiments. Modeling of bacterial inactivation was reviewed by Dalrymple et al. [15] for photocatalysis of water, and its mechanisms are well explained. More specifically, in their work the evolution was presented stating with the Chick model, the modification known as Chick-Watson Model, the delayed Chick-Watson Model, the Hom model and others; all were pre-cursors of the most sophisticated models to follow in the next years. For instance, the approaches of Geeraerd et al. [16] or Mafart et al. [17] have suggested in thermal inactivation of microorganisms, or the modifications Marugan et al. [18] have introduced for photo-catalysis, all contributed in understanding the bacterial inactivation process in depth, under various conditions, while being application-specific.

In fact, photocatalytic models have been found to resemble the simple photolytic ones, as stated by Gomes et al. [19]. Although the disinfectant source changes, the equation remains similar; hence the use of the same model for photolysis and photo-catalysis is valid. The change in the water matrix to wastewater, is however rather unexplored. Marugan et al. [20] have stated the modification of disinfection potentials when the chemistry of the matrix is altered and Salih [21] marked the importance of consideration of pollution load. Furthermore, Sichel et al. [22] and Rincon and Pulgarin [23] discussed the idea of minimum dose for inactivation and the importance of irradiation conditions on photolysis and Malato et al. [24] in their review mentioned the importance of light dispersion. These are factors that all co-exist in wastewater and affect the process more than drinking water.

Apart from disinfection modeling by solar light only, there are not enough systematic studies on bacterial kinetics in the solar post-irradiation period. Bacterial regrowth has been assessed in some works as an indicator of the quality of disinfection $[23,25]$, or well correlated in other UV sources [26], but apart from the biological aspects which are very well understood [27], the prediction of the phenomenon is rather fuzzy. Many authors in their works have studied the regrowth after the photo-treatment of water $[25,28]$, while some monitored the survival in wastewater [11] and other water matrices [29]. The presence of nutrient sources in wastewater offers growth potential for microorganisms, posing a direct threat by re-contamination of the water, so the prediction of the phenomenon should be assessed as well as the suggested pre-treatment conditions.

In this work, a series of solar disinfection experiments are presented, investigating the correlation between irradiation intensity and inactivation of bacteria, while equally focusing on the estimation of post-irradiation behavior. Lately, the semi-logarithmic and the Weibull models were verified as appropriate expressions of bacterial inactivation tests [30]. Here, a systematic study is presented, modeling 9 cases of bacterial disinfection with these expressions, in order to predict the outcome and more practically, the efficiency of solar disinfection. The subsequent regrowth was evaluated through the evolution of bacterial counts and their trends as a function of intensity and dose. Finally, the correlation between solar exposure and the bacterial regrowth kinetics is discussed.

\section{Materials and methods}

\subsection{Synthetic secondary effluent composition and preparation}

The wastewater composition followed the instructions of OECD [31] and consisted of $160 \mathrm{mg} / \mathrm{L}$ peptone ( ${ }^{2} \mathrm{CNS}$, Switzerland), $110 \mathrm{mg} / \mathrm{L}$ meat extract (Fluka, France), $30 \mathrm{mg} / \mathrm{L}$ urea (ABCR $\mathrm{GmbH}$, Germany), $28 \mathrm{mg} / \mathrm{L} \mathrm{K}_{2} \mathrm{HPO}_{4}$ (Sigma-Aldrich, Germany), $7 \mathrm{mg} / \mathrm{L} \mathrm{NaCl}$ (Fluka, France), $4 \mathrm{mg} / \mathrm{L} \mathrm{CaCl} 2 \cdot 2 \mathrm{H}_{2} \mathrm{O}$ (Fluka, France) and $2 \mathrm{mg} / \mathrm{L} \mathrm{MgSO}_{4} \cdot 7 \mathrm{H}_{2} \mathrm{O}$ (Sigma-Aldrich, Germany). The initial solution was subsequently diluted $10 \%$ in distilled water, as previously presented in $[13,46]$. The constituents were used as received.

The preparation of the microorganisms' suspension, i.e. E. coli strain K-12 (MG1655), which was supplied by the "Deutsche Sammlung von Mikroorganismen und Zellkulturen”, was analytically described elsewhere [13]. The resulting bacterial suspension withholds a concentration of $10^{9}$ colony forming units per $\mathrm{mL}$ $(\mathrm{CFU} / \mathrm{mL})$; therefore, $1 \mathrm{~mL}$ was introduced in $1 \mathrm{~L}$ of pre-sterilized wastewater to form an initial concentration of approximately $10^{6} \mathrm{CFU} / \mathrm{mL}$.

\subsection{Disinfection experiments and employed reactors}

The trials performed were batch tests under simulated solar light. The Pyrex glass reactors (of total volume $65 \mathrm{~mL}$ ) contained $50 \mathrm{~mL}$ of $E$. coli-spiked wastewater, while being stirred with a magnetic bar at low rotation speed $(200 \mathrm{rpm})$. A Suntest solar simulator bearing a $150-\mathrm{W}$ Xenon lamp provided with the light source $(0.5 \%$ in the UVB range, $5 \%$ in the UVA, while the higher wavelengths follow the solar spectrum) and the employed intensities were selected: 500, 600, 700, 800, 900, 1000, 1200, 1400 and $1600 \mathrm{~W} / \mathrm{m}^{2}$. The values above $1100 \mathrm{~W} / \mathrm{m}^{2}$ do not correspond to a simulation of actual solar measurements, but rather recreate conditions of artificially enhanced illumination conditions, such as compound parabolic collector reactors (CPCs) [32] with concentration ratios higher than 1 . The intensities were controlled by a Global and UV radiometer (Kipp \& Zonen Mod. CM3 and CUV3). Finally, temperature was monitored throughout the tests and remained below $40^{\circ} \mathrm{C}$.

\subsection{Bacterial sample analysis}

Sampling was made from the body of the sample under stirring and approximately $1 \mathrm{~mL}$ was drawn every $30 \mathrm{~min}$ (20 min for intensities $>1000 \mathrm{~W} / \mathrm{m}^{2}$ ). The samples were always kept in sterile plastic Eppendorf sealable vials, to ensure their sterile preservation. Experiments were conducted twice, plating was done in duplicates and in three consecutive dilutions were plated, to achieve measurable bacterial count on the plates; the optimal colony counts in this method are among 15-150. The spread-plate technique [47] was performed on non-selective plate count agar (PCA), contained in 9-cm plastic sterile Petri dishes. The detection limit for undiluted samples is $1 \mathrm{CFU} / \mathrm{mL}$ and $10 \mathrm{CFU} / \mathrm{ml}$ for the diluted ones [48,49]. All samples were kept for $48 \mathrm{~h}$ in the dark and post-irradiation monitoring was made every $24 \mathrm{~h}$ after the sampling, to measure survival and regrowth of the bacterial populations. Previous works within our group, in various environmentally relevant matrices indicated that after $48 \mathrm{~h}$ the trend (long term growth or decay) was not modified in the majority of the cases [29]. $24 \mathrm{~h}$ are not sufficient, since damaged cells often 
appeared to delay, but present zero viable cells afterwards, or a small decay period was followed by regrowth.

\subsection{Modeling of bacterial disinfection}

In order to model the bacterial response under the solar light stress, the GInaFiT freeware add-on for Microsoft Excel was used [33]. Between the models tested and fit the curves; Model 1: a Shoulder log-linear [16], Model 2: the Weibull frequency distribution model [17] were used, as they yielded the smallest MSE, highest $R^{2}$, and their calculation was possible for all cases (enough data points).

\subsubsection{Shoulder log-linear inactivation model}

The shoulder log-linear model was first suggested as two separate equations [16].

$\frac{d N}{d t}=-k_{\max } * N_{0} *\left(\frac{1}{1+C_{c}}\right) *\left(1-\frac{N_{\text {res }}}{N_{0}}\right)$

$\frac{d C_{c}}{d t}=-k_{\max } * C_{c}$

$C_{c}$ is related to the physiological cell state, $k_{\max }$ is the rate of inactivation (1/time unit), and $N_{\text {res }}$ is the residual density of the bacterial population $(\mathrm{CFU} / \mathrm{mL})$. By changing $C_{c}$ with $e^{k \operatorname{maxSl}}-1$, by $S l$ (time units) being the shoulder length (by integration of Eq. (2) and replacement to Eq. (1)), the final versions (3) and (4) are produced:

$N=N_{0} * \exp \left(-k_{\max } * t\right) *\left(\exp \left(k_{\max } * S l\right)\right) /\left(1+\left(\exp \left(-k_{\max } * S l\right)-1\right)\right.$

$$
\left.\left.* \exp \left(-k_{\max } * t\right)\right)\right)
$$

For identification purposes reformulated as:

$$
\begin{aligned}
\log _{10}(N)= & \log _{10}\left(N_{0}\right)-k * \frac{t-t_{s}}{\ln (10)} \\
& -\log _{10}\left[1+\left(\exp \left(k * t_{s}\right)-1\right) * \exp (-k * t)\right]
\end{aligned}
$$

where:

$N$ : the bacterial population at any given time $(\mathrm{CFU} / \mathrm{mL})$.

$N_{0}$ : the initial bacterial population $(\mathrm{CFU} / \mathrm{mL})$.

$t$ : the investigated time (s).

$t_{s}$ is the length of the shoulder period or threshold time to observe inactivation and

$k$ is the rate of the inactivation (i.e., slope of the linear portion).

\subsubsection{Weibull inactivation model}

The Weibull model is the Mafart suggestion to adapt the cumulative probability density function to microbial inactivation [17]. The effort is "to reduce naturally" the classic log-linear model, and is as follows:

$\frac{N}{N_{0}}=10^{\left(-\left(\frac{t}{\partial}\right)^{p}\right)}$

For identification purposes reformulated as:

$\log _{10} N=\log _{10} N_{0}-\left(\frac{t}{\delta}\right)^{p}$

where:

$N$ : the (residual) bacterial population at any given time $(\mathrm{CFU} / \mathrm{mL})$.

$N_{0}$ : the initial bacterial population $(\mathrm{CFU} / \mathrm{mL})$.

$t$ : the investigated time (s).

$\delta$ and $p$ : Weibull model-specific constraints (scale and shape parameters).

$\delta$ is a scale parameter and marks the time for the first decimal reduction. For $p<1$ concave curves are described and $p>1$ describes convex shapes. Finally, $\delta$ and $p$ are not independent; there is a strong correlation existing, as suggested by Van Boekel [34] and Mafart et al. [17], and is due to the model structure.

\section{Results and discussion}

\subsection{Simulated solar light disinfection experiments}

\subsubsection{Bacterial inactivation as a function of the light intensity}

Fig. 1 illustrates a synopsis of all the disinfection experiments conducted under simulated solar light. During these batch tests, E. coli dispersed in wastewater were exposed to solar light in a range of intensities from 500 to $1600 \mathrm{~W} / \mathrm{m}^{2}$. For analysis and clarity reasons, intensity levels will be divided as low (Supplementary Fig. 1-i), medium (Supplementary Fig. 1-ii) and high (Supplementary Fig. 1-iii) intensity levels.

At the low intensity experiments, some distinct phases can be observed. First of all, the bacterial population does not decrease until $180 \mathrm{~min}$ of continuous illumination, presenting an initial shoulder, as it was proposed by many works $[7,10,13]$. In addition, in the pre-mentioned works, this shoulder was not (or was mildly) accompanied by an increase in bacterial population. Here, a fluctuation is visible, reducing with increasing intensity. Literature suggests that this phenomenon is attributed to the simultaneous disinfecting action of light and (i) photo-activation of previously non-cultivable bacteria [25], (ii) an initial adaptation phase for bacterial population in the new dilution medium, with possible acclimatization shocks (which induce decay) and (iii) the growth of bacteria which is supported by this medium [20,35]; the presence of nutrients and ions enhances bacterial growth, and bacteria which have not been lethally damaged by the action of light undergo repair and are also able to reproduce and compensate for the lost numbers.

Afterwards, the initial shoulder is followed by a linear (in logarithmic plot of results) decay period. This phase fits to the behavior suggested by Geeraerd et al. [16]. Within the log-linear inactivation phase, there is a second delay phase towards its middle, which

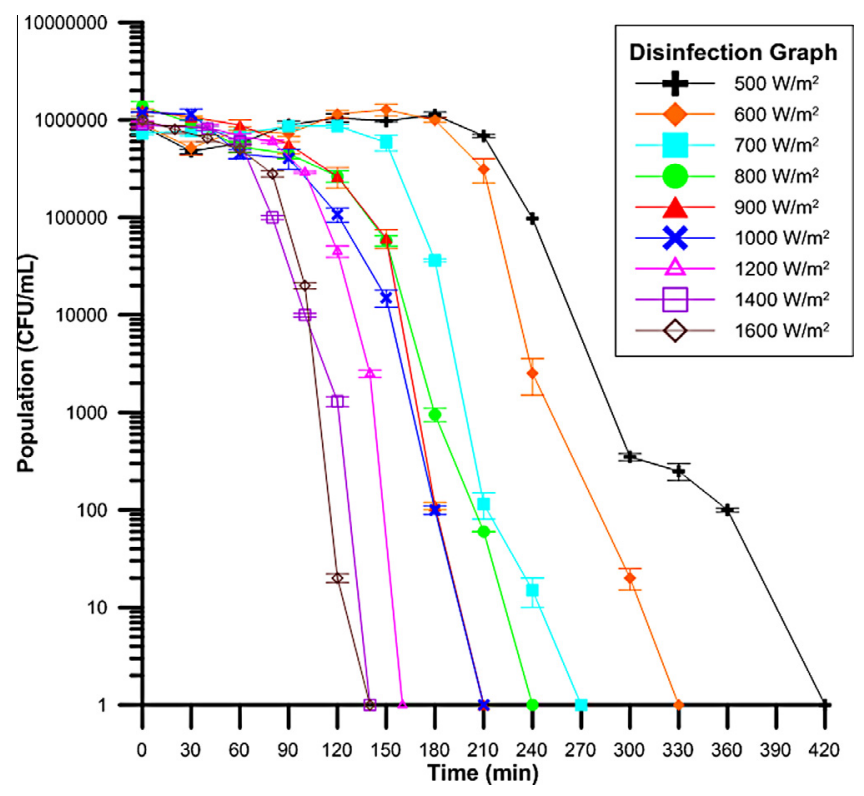

Fig. 1. Solar disinfection experiments under discrete irradiation intensities at laboratory scale. (i) Synopsis of the experiments. (ii) Low intensity experiments $\left(500-700 \mathrm{~W} / \mathrm{m}^{2}\right)$. (iii) Medium intensity experiments $\left(800-1000 \mathrm{~W} / \mathrm{m}^{2}\right)$. (iv) High intensity experiments $\left(1200-1600 \mathrm{~W} / \mathrm{m}^{2}\right)$. (For interpretation of the references to colour in this figure legend, the reader is referred to the web version of this article.) 
Table 1

Modeling details and analysis of fit for the shoulder log-linear and Weibull distribution model.

\begin{tabular}{|c|c|c|c|c|c|c|c|c|c|c|}
\hline \multicolumn{7}{|c|}{ Shoulder log-linear survival model } & \multicolumn{4}{|c|}{ Weibull distribution survival model } \\
\hline Intensity $\left(\mathrm{W} / \mathrm{m}^{2}\right)$ & $t_{s}(\min )$ & $k\left(\min ^{-1}\right)$ & $\log N_{0}(\mathrm{CFU} / \mathrm{mL})$ & RootMSE & $R^{2}$-(adj) & $\delta(\min )$ & $p$ & $\log N_{0}(\mathrm{CFU} / \mathrm{mL})$ & RootMSE & $R^{2}-(\operatorname{adj})$ \\
\hline 500 & 211.72 & 0.07 & 5.98 & 0.2764 & 0.9754 & 224.45 & 2.97 & 6.1 & 0.427 & 0.9413 \\
\hline 600 & 196.49 & 0.1 & 5.99 & 0.2341 & 0.9837 & 207.36 & 3.99 & 6.08 & 0.3764 & 0.9578 \\
\hline 700 & 151.76 & 0.12 & 6.05 & 0.239 & 0.9854 & 155.1 & 3.44 & 6.22 & 0.488 & 0.939 \\
\hline 800 & 129.77 & 0.12 & 5.67 & 0.2137 & 0.9853 & 133.7 & 3.07 & 5.87 & 0.2347 & 0.9823 \\
\hline 900 & 137.31 & 0.18 & 5.76 & 0.2993 & 0.971 & 137.21 & 4.25 & 5.93 & 0.3121 & 0.9684 \\
\hline 1000 & 125.45 & 0.15 & 5.69 & 0.3155 & 0.9676 & 125.53 & 3.48 & 5.89 & 0.2132 & 0.9852 \\
\hline 1200 & 115.64 & 0.21 & 5.89 & 0.5451 & 0.911 & 122.06 & 4.3 & 5.95 & 0.3461 & 0.9641 \\
\hline 1400 & 77.77 & 0.2 & 5.91 & 0.435 & 0.9481 & 87.32 & 3.73 & 5.97 & 0.2291 & 0.9856 \\
\hline 1600 & 83.52 & 0.25 & 5.83 & 0.2946 & 0.981 & 82.81 & 3.53 & 6.02 & 0.4789 & 0.9498 \\
\hline Average & 136.6 & 0.16 & 5.86 & 0.317 & 0.9676 & 141.73 & 3.64 & 6 & 0.345 & 0.9637 \\
\hline St. Dev. & 45.21 & 0.06 & 0.14 & 0.1073 & 0.0243 & 48.08 & 0.47 & 0.11 & 0.1062 & 0.0182 \\
\hline
\end{tabular}

has been encountered again in literature [36]. The authors suggested that the synergy between temperature and light action [4] was able to inflict the final damage and totally inactivate bacteria. For our experiments, we believe that this second plateau is related with adaptation of the bacterial species to UV light [38], and more flexible response to UVA stress; this second delay is decreasing with increasing intensities, fact that leads us to believe that it is dose-related, since the photon flux is very low. Also, temperature was always lower than $40{ }^{\circ} \mathrm{C}$ in these trials, and thermal inactivation is not expected. Afterwards, the resistance of the new strain is overpassed, leading to total inactivation. Finally, a clear correlation between the exposure time needed for total inactivation and the intensity can be observed, with higher intensities decreasing significantly the demand for exposure up to $55 \%$ for a $200 \mathrm{~W} / \mathrm{m}^{2}$ increase in intensity.

What is introduced in this work as medium intensities, are solar intensities in the relative high-end found in field disinfection applications. First of all, compared to the low intensity experiments, it is observed that the shoulder length is greatly reduced to 90$120 \mathrm{~min}$. Higher photon flux in the same system leads to more efficient disinfection, according to the multi-hit theory of Harm [37]. There is a certain " $n$ " number of hits a cell must receive in specific critical points in order to get inactivated. Berney et al. [7] have identified the targets, and therefore, the intensity increase is linked to increasing effective hits in the system. Also, the second lag period is almost $\left(800 \mathrm{~W} / \mathrm{m}^{2}\right)$ and totally $\left(900,1000 \mathrm{~W} / \mathrm{m}^{2}\right)$ suppressed. Finally, increasing the intensity from 800 to $1000 \mathrm{~W} / \mathrm{m}^{2}$ influences the exposure time necessary for total inactivation, with approximately $22 \%$ less required time. So far, increasing from doubling the intensity (500-1000 W/ $\mathrm{m}^{2}$ ) leads to halving the exposure time (420 to $200-210 \mathrm{~min}$ ).

The last plots presents the highest end of intensities employed in the study, from 1200 to $1600 \mathrm{~W} / \mathrm{m}^{2}$. Increasing intensity continued to decrease the shoulder length, to a minimum of approximately $80 \mathrm{~min}$, followed by acute log-linear decrease within the next $60 \mathrm{~min}$ after the shoulder is finished. In this case, the equilibrium set between the growth forces and the disinfecting action of light is imbalanced against $E$. coli very fast, indicating a possible minimum dose required for initiating the log-linear decay phase, as also suggested by Sichel et al. [22] and Ubomba-Jaswa et al. [5]. In total, increasing the intensity from 500 to $1600 \mathrm{~W} / \mathrm{m}^{2}$ has inflicted dramatic change to the necessary exposure time, with the initial $420 \mathrm{~min}$ being reduced to (approximately) $130 \mathrm{~min}$, which equals to $70 \%$ less time necessary. This decrease in percentage is very important, if extrapolation of the data is considered for the possible residence times in an application.

\subsubsection{Modeling of the inactivation data}

Table 1 presents analytical data concerning the parameters of the models. In order to diminish any small differences in initial

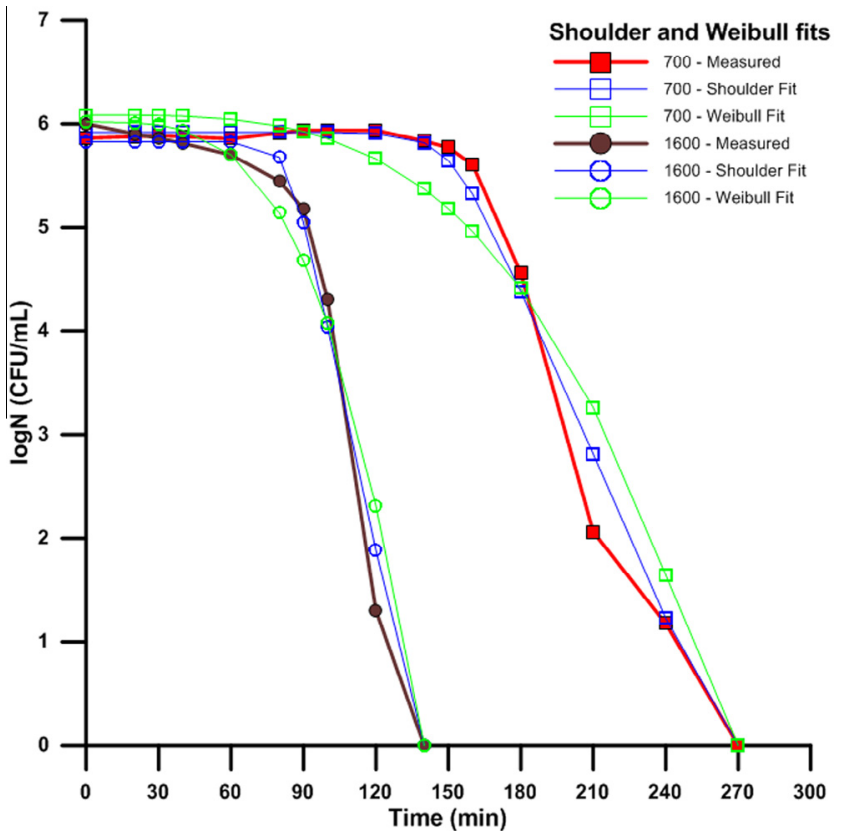

Fig. 2. Indicative model fits on a low and a high intensity plot. (For interpretation of the references to colour in this figure legend, the reader is referred to the web version of this article.)

population, data were normalized (reduction to $0-1$ scale and projected to $10^{6}$ ) prior to fitting. As far as the shoulder log-linear model is concerned, the fit approximation is very good (average $R^{2}$-adj: $\left.96.76 \%\right)$ with very low RMSE (0.317). Also, the decreasing tendency in the length of the shoulder $\left(t_{s}\right)$ is confirmed while in the same time $k$ is increasing, and the calculated $N_{0}$ is presented. Although the calculated $N_{0}$ value is always lower than the experimentally measured, it does seem to affect the model results significantly. For the Weibull model, a decreasing $\delta$ value is also seen, which is related with the delay of the decay phase. The results of the fit are good (average $R^{2}$-adj: $96.37 \%$ ), and the MSE is also low (0.345).

In overall, the shoulder-log linear model fits better our experimental data. Some indicative cases are given in Fig. 2, and the Figs. S2-S4 of the Supplementary material, where the fitting in the measured data is analytically presented. When explaining the experimental results, a decrease in the shoulder length was noted and the inactivation time in total, as intensity increased. This change is reflected to the selected models as well. The most important suggestion these linear models provide, is the correlation between the fitting parameters and the intensity levels. There is an initial population subject to a certain time of solar exposure 
at an intensity. Even if these constraints are not constant, the accumulated dose could be a good alternative to be inserted and generalize the mathematical expressions, as will be discussed below.

\subsubsection{Solar wastewater disinfection and dose dependence}

The analysis of the kinetic models fit before have indicated the mathematical expressions describing solar disinfection of wastewater, according to the intensity acquired in the solar simulator. There is however a need to standardize somehow the photon energy that the system needs in order to be sterilized. Rincon and Pulgarin [23] have indicated the need to standardize the results, in order to achieve comparable results among the researches in field trials for drinking water. They have put the dose under question, and decided that it is not an appropriate indicator for efficiency. In the same way, Ubomba-Jaswa et al. [5] in drinking water, Ndounla et al. [40] in photocatalysis and many others, have all conducted experiments at different times during the day and have concluded that in general, the same dose has the same effect when it is a result of high intensities. This suggests a shorter exposure at higher irradiance to achieve better disinfection results.

In these experiments, since the irradiation intensity is relatively high, constant and the measurements are frequent, the kinetic figures can be converted to "log population vs. dose" ones. Fig. 3(a and b) presents the normalized disinfection results presented in Fig. 1, but in terms of dose. In Fig. 3a, it is noticed that all the range of intensities requires approximately the same amount of solar energy in order to achieve total disinfection (i.e. zero viable counts) around $3200 \mathrm{~W} \mathrm{~h} / \mathrm{m}^{2}$ (range: $3100-3700$ ). In 8 of 9 conditions total inactivation is achieved with a dose between 3150 and $3500 \mathrm{~W} \mathrm{~h} / \mathrm{m}^{2}$. Furthermore, in Fig. $3 \mathrm{~b}$ the percent of bacteria eliminated are shown, as a function of each intensity level versus the dose. Although most of the kinetic curves display directly a reduction in the bacterial numbers since the beginning of the process, the curves of 500,600 and $700 \mathrm{~W} / \mathrm{m}^{2}$ present a decrease in numbers, then reverse effects and, afterwards, continuous and monotonous inactivation. This phenomenon was previously observed in the fluctuations in Fig. 1.

However, even in these low intensities, there is an energy threshold that initiates permanent inactivation, corresponding with the existence of the lag/shoulder phase, around $1200 \mathrm{~W} \mathrm{~h} / \mathrm{m}^{2}$. Beyond this point, all kinetic curves demonstrate

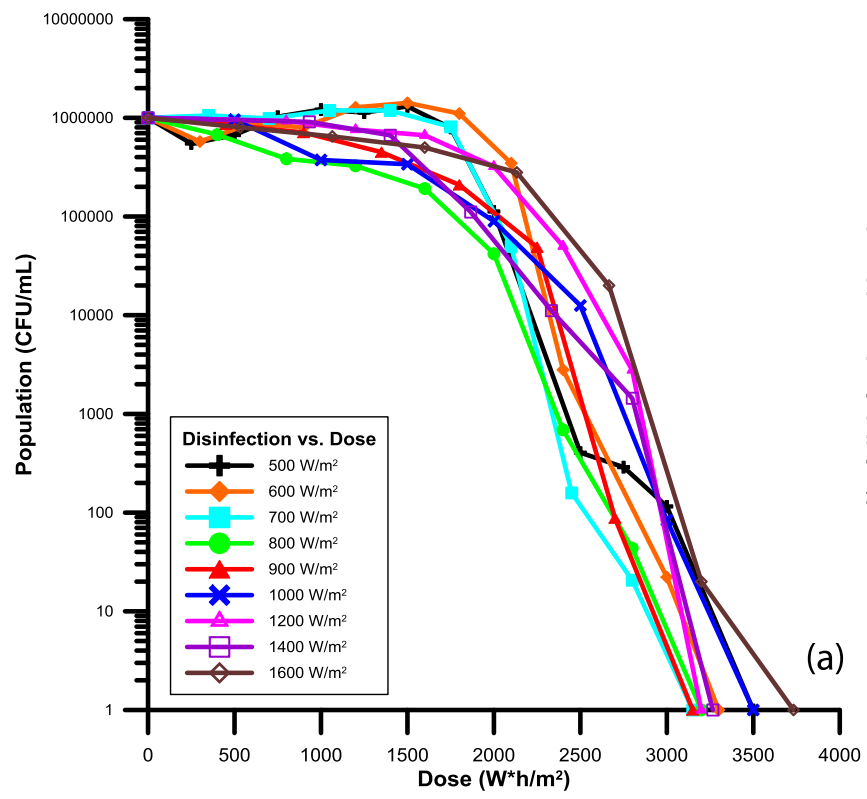

consistent inactivation, with even increasing inactivation rates. First of all, it is known that the accumulation of photoproducts in the bacterial cell leads to cell death [23]. Then, there is a certain number of targets solar light can attack, such as respiration chain [42], or the double DNA strand, but bacteria can heal this damage through a light-induced enzymatic process, known as photoreactivation. Under this scope, the accumulation of a certain amount of energy is necessary to cause permanent effects on bacteria [43] or to throw them in a viable, but not cultivable state [25]. From the observations above, it can be concluded that the constant supply of light leads to adaptation of the population on the stress conditions, also verified by Berney et al. [38] and therefore the phenomenon of persistence as suggested by Giacobone and Opezzo [39] can explain these findings. The new generations of bacteria that derive from stressed ones are more prone to survive the light impact [41] and even adapt better to a new stress [29]. It should also be noted here that the non-lethal light also provides the opportunity for excess growth, due to the nutrients present in the matrix. However, these effects are diminished as irradiation intensity increases.

Finally, modeling with GInaFiT also provides information for the estimated time necessary for 4-log reduction per every model. This value corresponds to the required time for exposure to the inactivating source, to achieve a reduction of 4 logarithmic units (99.99\% reduction of the initial concentration). This measurement is used here as a common reference applicable in all models. Table 2 summarizes the necessary times for this level of removal, where for both models the times are very close. In fact, as intensity increases the models estimate closer required 4-log inactivation times. Knowing the intensity that caused the inactivation, the necessary dose for $99.99 \%$ disinfection can be calculated. As it seems, the final dose is affected by the sampling interval, but in general, a dose around $2900 \pm 200 \mathrm{Wh} / \mathrm{m}^{2}$ results in 4-log reduction of the population.

\subsection{Post-irradiation response in the dark}

\subsubsection{Dark repair dynamics}

The second part of the investigation deals with the post-irradiation period, while storing the photo-treated synthetic wastewater in the dark for a consequent period of $48 \mathrm{~h}$. For clarity

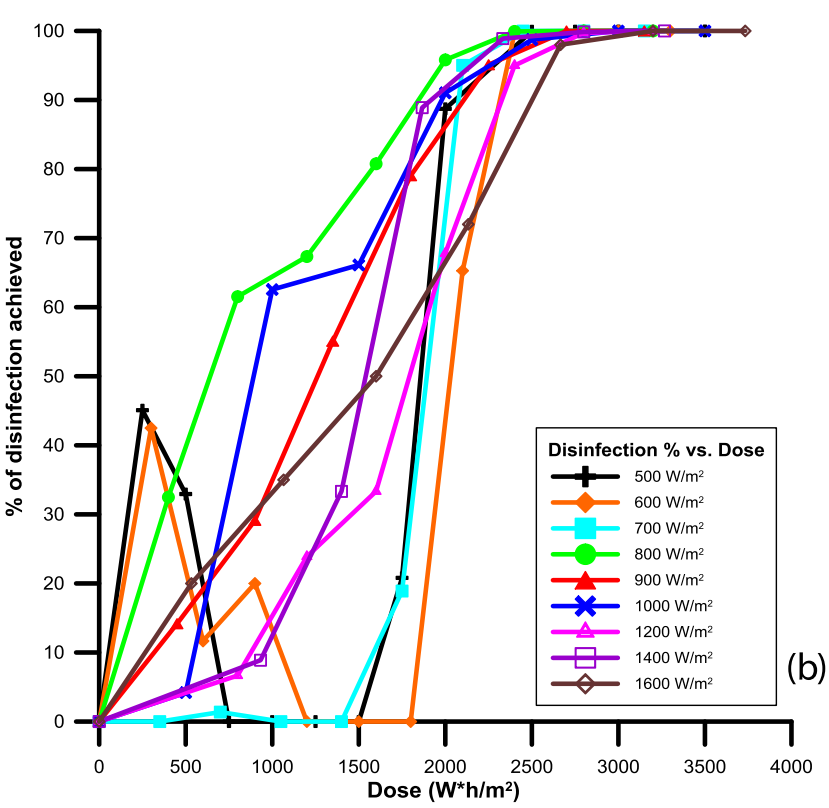

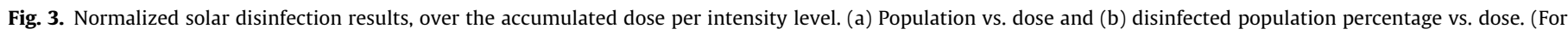
interpretation of the references to colour in this figure legend, the reader is referred to the web version of this article.) 
Table 2

Required time and dose for 4-log (99.99\%) removal per intensity and model.

\begin{tabular}{lllll}
\hline $\begin{array}{l}\text { Solar } \\
\text { intensity } \\
\left(\mathrm{W} / \mathrm{m}^{2}\right)\end{array}$ & $\begin{array}{l}\text { Shoulder } \\
\text { model: } \\
\text { required time } \\
(\mathrm{min})\end{array}$ & $\begin{array}{l}\text { Weibull } \\
\text { model: } \\
\text { required } \\
\text { time }(\mathrm{min})\end{array}$ & $\begin{array}{l}\text { Shoulder } \\
\text { model: } \\
\text { required dose } \\
\left(\mathrm{W} \mathrm{h} / \mathrm{m}^{2}\right)\end{array}$ & $\begin{array}{l}\text { Weibull } \\
\text { model: } \\
\text { required dose } \\
\left(\mathrm{W} \mathrm{h} / \mathrm{m}^{2}\right)\end{array}$ \\
\hline 500 & 353 & 361 & 2942 & 3008 \\
600 & 287 & 293 & 2870 & 2930 \\
700 & 227 & 232 & 2648 & 2707 \\
800 & 209 & 211 & 2787 & 2813 \\
900 & 189 & 191 & 2835 & 2865 \\
1000 & 187 & 189 & 3117 & 3150 \\
1200 & 152 & 154 & 3040 & 3080 \\
1400 & 125 & 127 & 2917 & 2963 \\
1600 & 122 & 123 & 3253 & 3280 \\
Average dose: & & 2934 & 2977 \\
St. Dev.: & & & 181 & 176 \\
\hline
\end{tabular}

reasons, the results will be split, according to the intensity levels, in Fig. 4(a-c, low intensity), Fig. 5(a-c, medium intensity) and Fig. 6(a-c, high intensity). In all figures, the same color represents the same sampling time, for instance the red line represents samples irradiated for $120 \mathrm{~min}$ and then stored in the dark. In a given figure, each intensity level has a different trace. Also, for each intensity level six representative kinetic curves are shown (four in high intensities), according to the behavior of the microorganisms (growth or decay). Finally, no regrowth was observed when total inactivation was observed.

Fig. 4 represents the low intensity experiments, here 500, 600 and $700 \mathrm{~W} / \mathrm{m}^{2}$. As it can be observed, regrowth of the bacterial population changes as the inflicted intensity is changed. When intensity is increased, the same sampling intervals present different behavior. A general trend indicates a decrease in the population as intensity increases. For instance, samples retrieved after $150 \mathrm{~min}$ of exposure, at $500 \mathrm{~W} / \mathrm{m}^{2}$ present growth after $48 \mathrm{~h}$, are marginally stationary (slight decrease) at $600 \mathrm{~W} / \mathrm{m}^{2}$ and clearly decrease, when exposed to $700 \mathrm{~W} / \mathrm{m}^{2}$.

For the medium intensity experiments $\left(800-1000 \mathrm{~W} / \mathrm{m}^{2}\right)$, in Fig. 5 the response in the same sampling intervals, from 30 to $180 \mathrm{~min}$ is presented. It is found that one of the most visible changes is the behavior of the samples irradiated for $180 \mathrm{~min}$, which are now completely decaying within the first $24 \mathrm{~h}$. The damages accumulated differ from one intensity level to another, and after the extent of damage in disinfection, the differences in the inability to recover the damage done within $48 \mathrm{~h}$ are noticeable. However, the differences among the three levels are relatively small and some changes are visible only in long term; for instance, samples drawn between 90 and $150 \mathrm{~min}$ are presenting fluctuations in the bacterial numbers but the kinetic curves shape shifts from concave to convex, indicating the pre-determined decay.

Finally, similar observations can be made for the high intensity regrowth curves, presented in Fig. 6. It is seen that increasing the intensity causes a change in the bacterial ability to heal their damages, as from 60 to $80 \mathrm{~min}$ only, the damage seems more than their potential healing abilities. Also, as few as $20 \mathrm{~min}$, in such high intensities can cause change in the long term behavior; for instance, the 60-min kinetic curve, which turned into a clear decay curve.

\subsubsection{Investigation on the effective bacteriostatic dose}

Further analysis of the regrowth data, can provide with observations on the role of the dose. In mathematic terms, a change in the post-irradiation curves from concave to convex ones was observed, as intensity increased; formerly regrowth lines are later representing decay ones. As the time of the sampling is not modified, but intensity is, the received dose during disinfection is increased and as a consequence, so is the post-irradiation behavior. This result is characterized as the effective bacteriostatic dose (EBD), measuring the tipping point to render organisms non-cultivable, in long term.

These changes in behavior are summarized in Table 3. The observations of the kinetic curves provide the information on the response during the dark period. Having taken samples in relatively short intervals, the curves presented as "GROWTH" are the curves that in overall or long term presented increase of the population and "DECAY" the ones that show permanent or long term decrease of the population. As it seems, this change is not linear; increasing the intensity does not lead to infinite decrease of the ability to recover, because at high irradiation intensities, the limitation of the process is not really the diffusion of light in bacteria, but the saturation of the disinfecting action of the light. As a matter of fact, along with the increase of the intensity, the same system receives higher doses, and if the light action mode against bacteria $[7,37]$ is considered, the possibility of inflicting damage in critical areas is not increased. It was also suggested by Sichel et al. [22], in experiments conducted in solar light, increasing the dose did not result to great enhancement of disinfection; this was also the case for the disinfection experiments. As it is concluded now, this effect is also true for regrowth.

Furthermore, if virtual 5-min intervals are interpolated between the sampling times, and combined with the present data from the regrowth curves, an approximation of the point when bacteria change their behavior from "GROWTH" to "DECAY" can be made. For instance, in $500 \mathrm{~W} / \mathrm{m}^{2}$, the 120 -min curve presents growth,

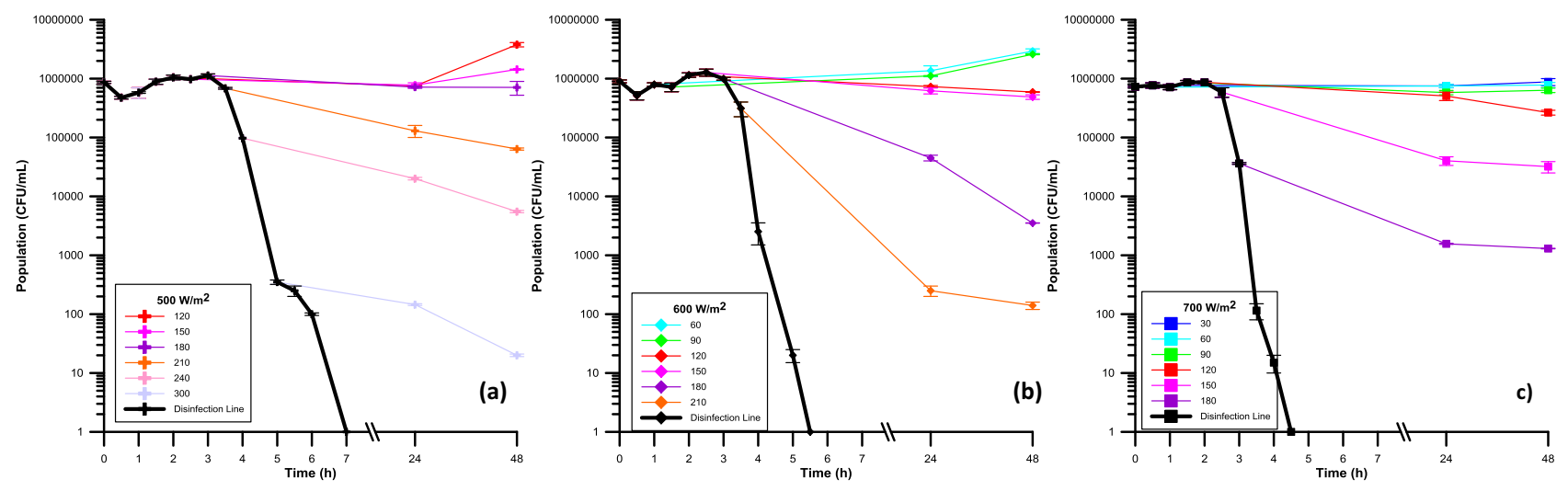

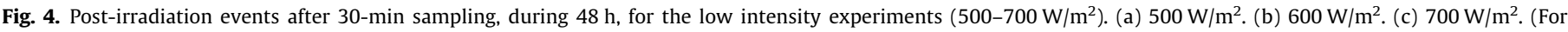
interpretation of the references to colour in this figure legend, the reader is referred to the web version of this article.) 

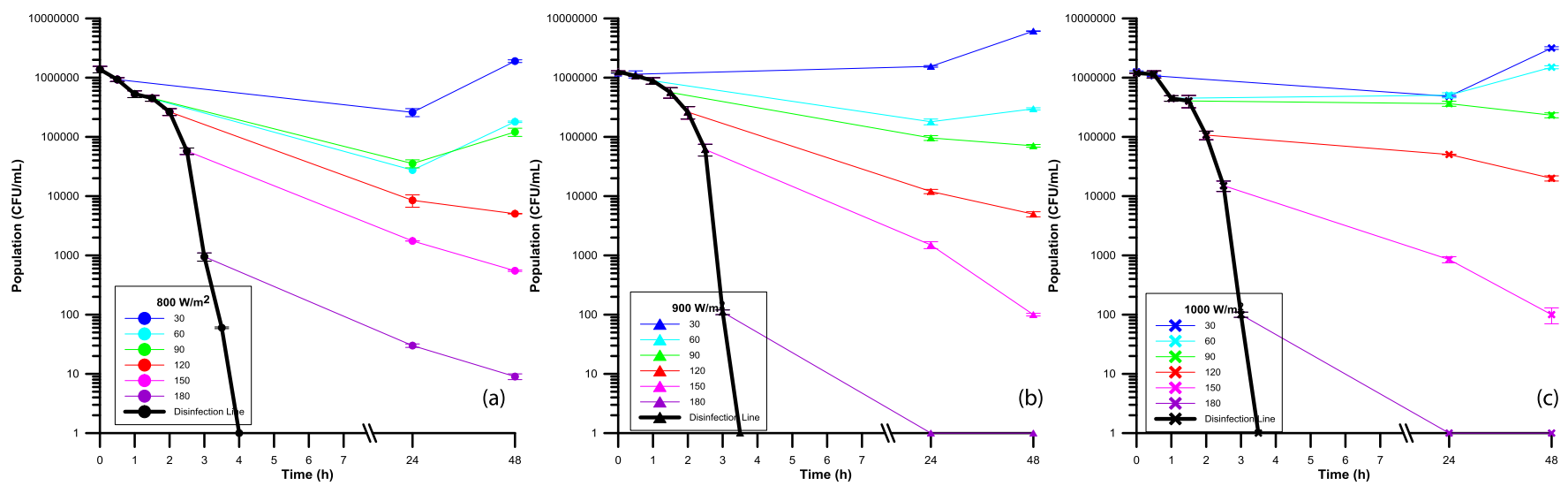

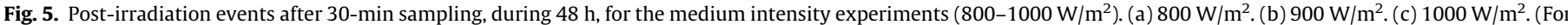
interpretation of the references to colour in this figure legend, the reader is referred to the web version of this article.)
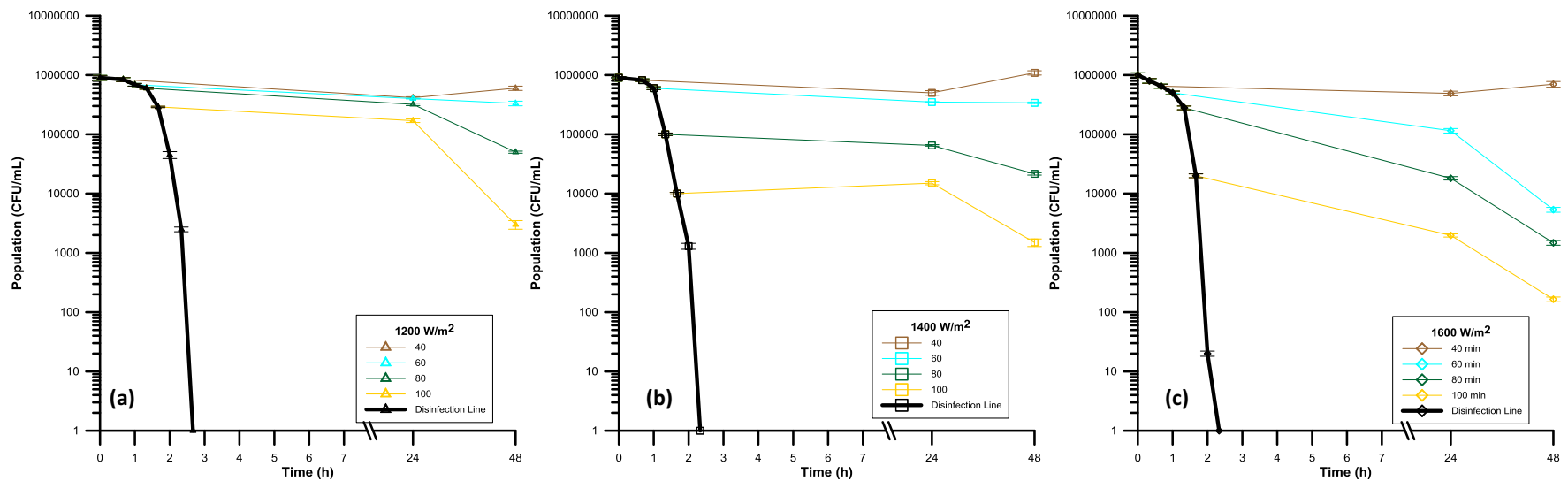

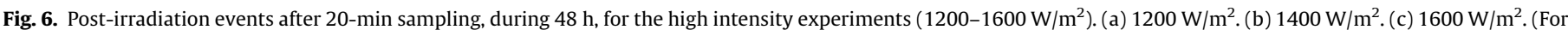
interpretation of the references to colour in this figure legend, the reader is referred to the web version of this article.)

Table 3

Summary of the post-irradiation changes in bacterial behavior according to the inflicted intensity.

\begin{tabular}{|c|c|c|c|c|c|c|c|c|c|}
\hline $\begin{array}{c}\text { Time } \\
(\mathrm{min}) / \\
\text { Intensity } \\
\left(\mathbf{W} / \mathbf{m}^{2}\right)\end{array}$ & 500 & 600 & 700 & 800 & 900 & 1000 & 1200 & 1400 & 1600 \\
\hline 0 & GROWTH & GROWTH & GROWTH & GROWTH & GROWTH & GROWTH & GROWTH & GROWTH & GROWTH \\
\hline 20 & GROWTH & GROWTH & GROWTH & GROWTH & GROWTH & GROWTH & GROWTH & GROWTH & GROWTH \\
\hline 30 & GROWTH & GROWTH & GROWTH & GROWTH & GROWTH & GROWTH & GROWTH & GROWTH & GROWTH \\
\hline 40 & GROWTH & GROWTH & GROWTH & GROWTH & GROWTH & GROWTH & GROWTH & GROWTH & GROWTH \\
\hline 60 & GROWTH & GROWTH & GROWTH & GROWTH & GROWTH & GROWTH & DECAY & DECAY & DECAY \\
\hline 80 & GROWTH & GROWTH & GROWTH & GROWTH & GROWTH & DECAY & DECAY & DECAY & DECAY \\
\hline 90 & GROWTH & GROWTH & GROWTH & GROWTH & DECAY & DECAY & DECAY & DECAY & DECAY \\
\hline 100 & GROWTH & GROWTH & DECAY & DECAY & DECAY & DECAY & DECAY & DECAY & DECAY \\
\hline 120 & GROWTH & DECAY & DECAY & DECAY & DECAY & DECAY & DECAY & DECAY & DECAY \\
\hline 140 & GROWTH & DECAY & DECAY & DECAY & DECAY & DECAY & DECAY & DECAY & DECAY \\
\hline 150 & GROWTH & DECAY & DECAY & DECAY & DECAY & DECAY & DECAY & & \\
\hline 160 & GROWTH & DECAY & DECAY & DECAY & DECAY & DECAY & DECAY & & \\
\hline 180 & DECAY & DECAY & DECAY & DECAY & DECAY & DECAY & & & \\
\hline 210 & DECAY & DECAY & DECAY & DECAY & DECAY & DECAY & & & \\
\hline 240 & DECAY & DECAY & DECAY & DECAY & & & & & \\
\hline 270 & DECAY & DECAY & DECAY & & & & & & \\
\hline 300 & DECAY & DECAY & & & & & & & \\
\hline 330 & DECAY & DECAY & & & & & & & \\
\hline 360 & DECAY & & & & & & & & \\
\hline 390 & DECAY & & & & & & & & \\
\hline 420 & DECAY & & & & & & & & \\
\hline
\end{tabular}


Table 4

Investigation on the effective bacteriostatic dose (EBD).

\begin{tabular}{llllll}
\hline $\begin{array}{l}\text { Intensity } \\
\left(\mathrm{W} / \mathrm{m}^{2}\right)\end{array}$ & $\begin{array}{l}\text { Time } \\
\mathrm{min} \\
(\mathrm{min})\end{array}$ & $\begin{array}{l}\text { Time } \\
\max \\
(\mathrm{min})\end{array}$ & $\begin{array}{l}\text { Dose min } \\
\left(\mathrm{W} \mathrm{h} / \mathrm{m}^{2}\right)\end{array}$ & $\begin{array}{l}\text { Dose max } \\
\left(\mathrm{W} \mathrm{h} / \mathrm{m}^{2}\right)\end{array}$ & $\begin{array}{l}\text { EBD average } \\
\left(\mathrm{W} \mathrm{h} / \mathrm{m}^{2}\right)\end{array}$ \\
\hline 500 & 155 & 165 & 1291.7 & 1375 & 1333.3 \\
600 & 110 & 120 & 1100 & 1200 & 1150 \\
700 & 100 & 110 & 1166.7 & 1283.3 & 1225 \\
800 & 90 & 100 & 1200 & 1333.3 & 1266.7 \\
900 & 75 & 85 & 1125 & 1275 & 1200 \\
1000 & 65 & 75 & 1083.3 & 1250 & 1166.7 \\
1200 & 50 & 60 & 1000 & 1200 & 1100 \\
1400 & 45 & 55 & 1050 & 1283.3 & 1166.7 \\
1600 & 40 & 50 & 1066.7 & 1333.3 & 1200 \\
Average & 81.1 & 91.1 & 1120.4 & 1281.5 & 1200.9 \\
St. Dev & & & & & 68.5 \\
\hline
\end{tabular}

the 150 -min as well, but less and the 180 -min curve presents decay. By interpolation through the bacterial population data, it is suggested that the time point, which changed the bacterial curve from growth to decay, was around 155-160 min. In the same manner, this point in every curve is found, and the details are summarized in Table 4.

As it can be seen, the effective bacteriostatic dose has proved to be a well-defined energy threshold: when it is crossed, it determines the bacterial fate. The analysis of each curve provides with an EBD between 1120 and $1280 \mathrm{Wh} / \mathrm{m}^{2}$. The sampling intervals, as above for total inactivation times, inflicted minor changes in the results, as well as the estimation of the time points, especially at high intensities. In overall, an average dose of $1200 \pm 70 \mathrm{Wh} / \mathrm{m}^{2}$ has a bacteriostatic effect in long term. It was also observed that this energy threshold was very close in all intensities, resulting in a direct estimation of the theoretical exposure time required for total inactivation. Finally, along with the estimation of the population done before, one can predict the behavior of the microorganisms only by the dose received, which allows to foresee the growth or the decay of the bacteria in long term.

\subsection{Reciprocity law in solar disinfection of wastewater}

In 1964 , the reciprocity law was suggested [44] to interpret the behavior of different photochemical applications, indicating that the same dose will have the same effect on the various targets. In terms of energy, it suggests that the same light dose has the same effect, if it is a result of low irradiation intensity for a long time or if it is produced by high intensities for a short time. Since the first statement of the law, there have been many works that do not to comply with this formulation, reviewed also in 2003 by Martin et al. [45]. As it was suggested, the main reason for failing is the application of very high or very low intensities. What is considered "high" or "low" will be discussed later.

In a previous work within our Group, the reciprocity law was verified only for very few cases of temperature-controlled experiments, but the study included few intensity levels (and relatively high) [46]. Here, a wide range of intensities was investigated, from 500 to $1600 \mathrm{~W} / \mathrm{m}^{2}$, in order to have dense data and create a link between solar light intensity and dose, with their results. A convergence is observed around $2900 \mathrm{~W} \mathrm{~h} / \mathrm{m}^{2}$ for $99.99 \%$ disinfection efficiency, with the equivalent for inflicting enough damage to inactivate bacteria in long term (effective bacteriostatic dose) being around $1200 \mathrm{Wh} / \mathrm{m}^{2}$ (Tables 2 and 4). These levels, with a small deviation $(6.9 \%$ and $5.8 \%$, for 4 -log reduction and EBD, respectively), were found to be accurate.

In Fig. 7, an overview of normalized disinfection and regrowth results for all intensities and the corresponding doses is presented. What is observed, is the compliance with the reciprocity law, but not as a mathematical product of the "Intensity $\times$ time" principle; for instance in Fig. 7a, for the same dose, results are similar, but moving horizontally, specific intensity levels will not result in exactly the same effect. The intensities at opposite edges present slightly different effect (e.g. $500 \mathrm{~W}^{*} \mathrm{~h} / \mathrm{m}^{2}$, for 500 or $1600 \mathrm{~W} / \mathrm{m}^{2}$ ). Similarly, differences appear if very low or very high intensities are examined. Therefore, it is suggested that for solar wastewater disinfection, the reciprocity law is valid, under some restrictions: for the same dose, the same effect is observed, but for a margin of intensities, here being $600-1000 \mathrm{~W} / \mathrm{m}^{2}$. Outside this area, mild deviations occur. For stepwise increases of dose, the results improve. Furthermore, in regrowth tests, after $24 \mathrm{~h}$ only minor differences are observed, but it is noted that the highest values appear in low doses from low intensities. After $48 \mathrm{~h}$, the behavior is similar for similar dose levels, with lightly better results in high intensities. It must be noted here that the growth support provided by the wastewater matrix dynamically influences the deviations, because the excess growth of bacteria creates more targets for inactivation, with the same applied dose.

As it can be concluded, when experimenting at very low or very high intensities, as defined in these experiments, minor deviations from the reciprocity law can be present. The explanation in low range lies within the low energy levels provided to the samples, which cannot inflict higher decay force than the growth due to the matrix specification [49], while within the high intensity range, the degradation rate is probably lower than the photon supply and further increase of light does not inflict higher damage: as it was noticed in the disinfection graphs and Table 3, beyond a point, near the flux caused at $1200 \mathrm{~W} / \mathrm{m}^{2}$, light saturation conditions dominate, and the subsequent increase in intensity does not really reflect in faster degradation (few minutes improvement). However, even at the conditions tested in this work, with this matrix, the reciprocity law was confirmed for the majority of cases.

\section{Conclusions}

In the present work, in all simulated solar light wastewater disinfection experiments, the decay period was presented with a lag, namely shoulder phase. Increasing the intensity decreased the length of the lag period, as well as the fluctuations in the population, induced by the growth support of the matrix. Above $700 \mathrm{~W} / \mathrm{m}^{2}$ the second (minor) lag phase towards the end is diminished and beyond $900 \mathrm{~W} / \mathrm{m}^{2}$, no fluctuations are observed whatsoever.

The models used to fit the experimental data were the Shoulder Log-Linear and the Weibull distribution model. Through the fit, the shoulder length was identified, along with its correspondence with the inflicted dose. The decay phase was then estimated and the respective $k$ values or the shape and scale parameters, indicated a correlation with the light intensity. Also, intensity was related with the efficient energy to inactivate $99.99 \%(4-\log )$ of the total population.

One of the most significant findings was the constant, coherent character of the required dose, as far as disinfection is concerned. For any given intensity, the dose required to inactivate $99.99 \%$ was nearly constant $\left(2934 \pm 181 \mathrm{~W} \mathrm{~h} / \mathrm{m}^{2}\right.$ and $2977 \pm 176 \mathrm{~W} \mathrm{~h} / \mathrm{m}^{2}$ for the shoulder log-linear and Weibull model, respectively), while total inactivation required another almost constant dose $3200 \mathrm{~W} \mathrm{~h} / \mathrm{m}^{2}$ (range: $3100-3700$ ). This gives indications for standardization of the required dose, when a solar wastewater disinfection unit will be studied.

When it comes to regrowth, no regrowth was observed in the cases that total inactivation was reached. It was also found that there is a certain energy threshold in each discrete intensity level, after which regrowth turns into decay. This point was shown to be 


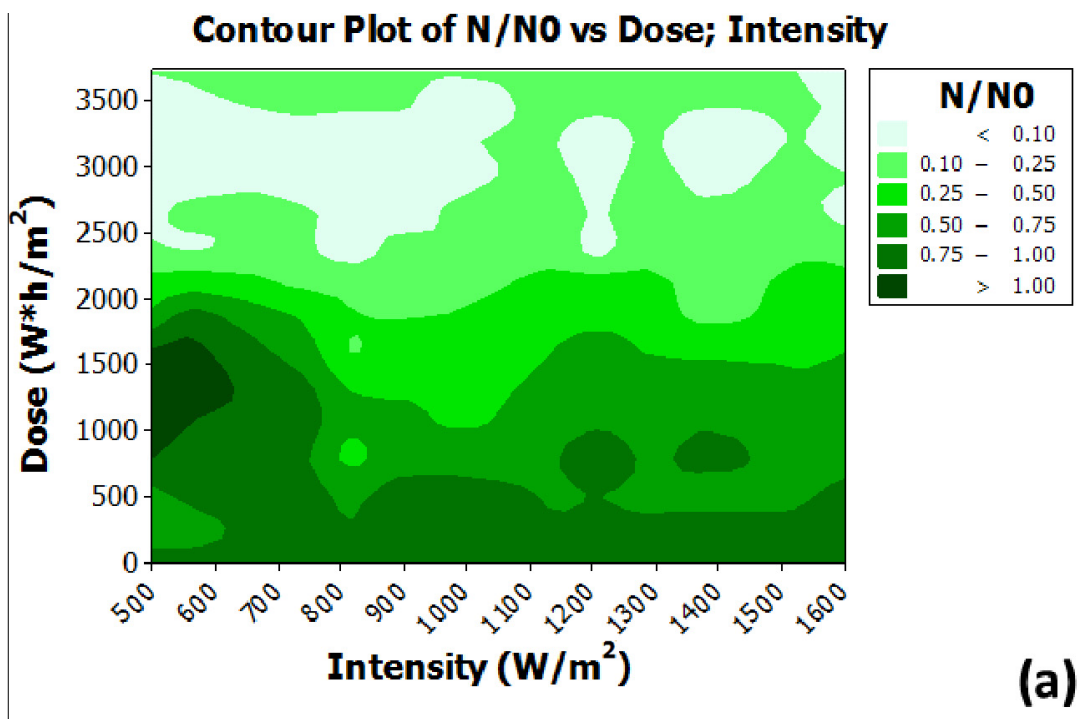

\section{Contour Plot of N/ NO at 24h vs Dose; Intensity}
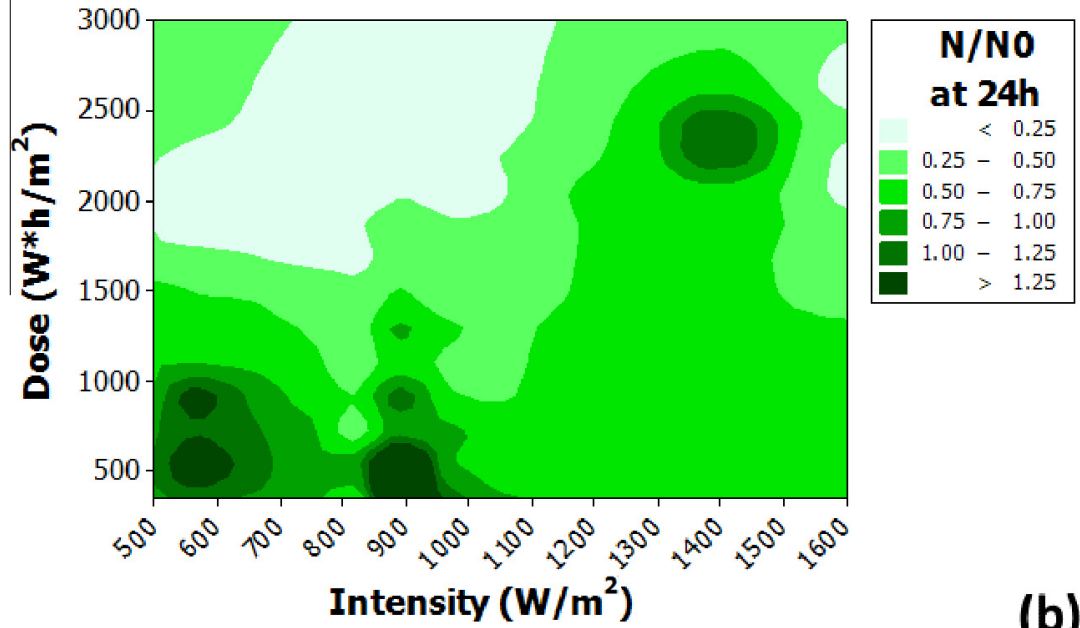

(b)

\section{Contour Plot of N/NO at 48h vs Dose; Intensity}

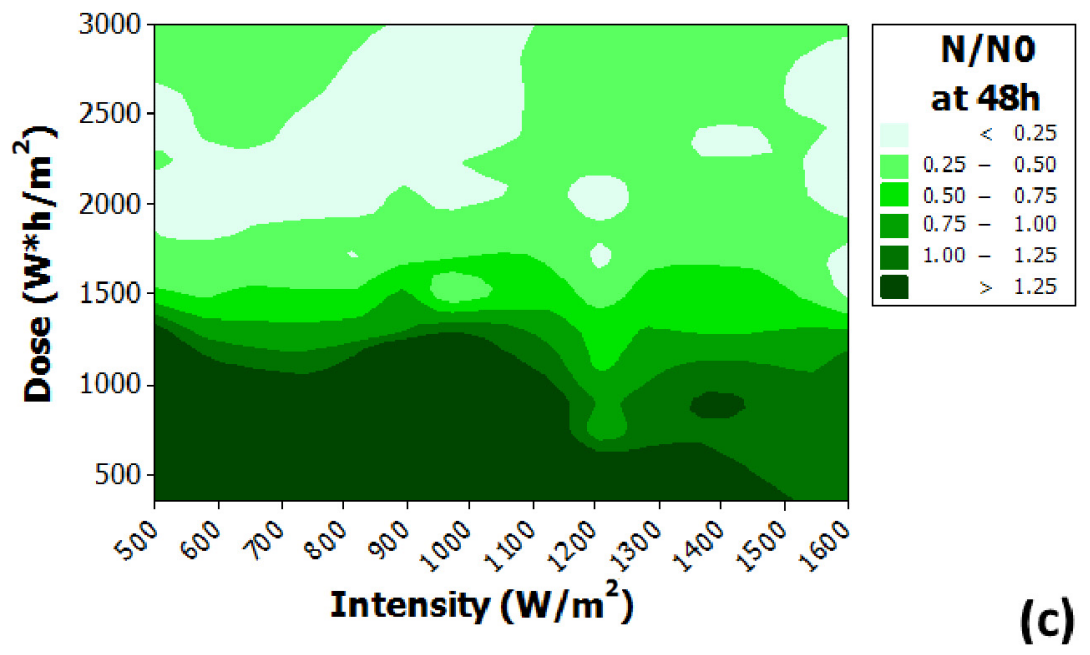

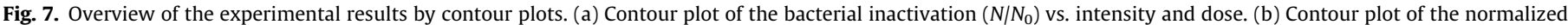

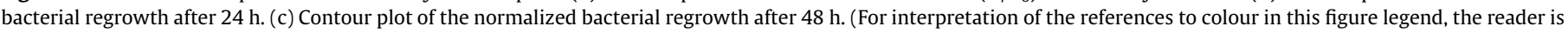
referred to the web version of this article.) 
delayed, as intensities dropped. However, the total accumulated dose to cause a bacteriostatic effect was the same in every case. There exists an energy threshold, the effective bacteriostatic dose (EBD) once achieved, one can assume deterministic long term decay for the surviving population.

In conclusion, the estimations of the bacterial kinetics during irradiation and the post-irradiation events were directly correlated with mathematical concepts. The link between the bacterial behavior during and after irradiation and the dose, allows the estimation of a bacterial life cycle, to say, according to their initial population and the treatment conditions. Finally, since the dose was found to have relatively the same effect, the reciprocity law seems to comply with only minor deviations. However, the hypothesis of constant irradiation is far from the real context, and before definite results, even at laboratory scale, more trials need to test the bacterial response in variable intensities, in randomized manner, for the proper generalization of the solar wastewater disinfection process.

\section{Acknowledgments}

Stefanos Giannakis acknowledges the Swiss Agency for Development and Cooperation (SDC) and the Swiss National Foundation for the Research for Development Grant for funding through the project "Treatment of the hospital wastewaters in Côte d'Ivoire and in Colombia by advanced oxidation processes" (Project No. 146919).

\section{Appendix A. Supplementary data}

Supplementary data associated with this article can be found, in the online version, at http://dx.doi.org/10.1016/j.cej.2015.06.077.

\section{References}

[1] A. Acra, Z. Raffoul, Y. Karahagopian, Solar disinfection of drinking water and oral rehydration solutions: guidelines for household application in developing countries, 1984

[2] J. Mwabi, F. Adeyemo, T. Mahlangu, B. Mamba, B. Brouckaert, C. Swartz, G. Offringa, L. Mpenyana-Monyatsi, M. Momba, Household water treatment systems: a solution to the production of safe drinking water by the low-income communities of Southern Africa, Phys. Chem. Earth Parts A/B/C 36 (2011) 1120-1128.

[3] M. Wegelin, S. Canonica, K. Mechsner, T. Fleischmann, F. Pesaro, A. Metzler, Solar water disinfection: scope of the process and analysis of radiation experiments, AQUA 43 (1994) 154-169.

[4] K. McGuigan, T. Joyce, R. Conroy, J. Gillespie, M. Elmore-Meegan, Solar disinfection of drinking water contained in transparent plastic bottles: characterizing the bacterial inactivation process, J. Appl. Microbiol. 84 (1998) 1138-1148.

[5] E. Ubomba-Jaswa, C. Navntoft, M.I. Polo-Lopez, P. Fernandez-Ibanez, K.G. McGuigan, Solar disinfection of drinking water (SODIS): an investigation of the effect of UV-A dose on inactivation efficiency, Photochem. Photobiol. Sci. 8 (2009) 587-595.

[6] K.G. McGuigan, R.M. Conroy, H.J. Mosler, M. du Preez, E. Ubomba-Jaswa, P. Fernandez-Ibanez, Solar water disinfection (SODIS): a review from bench-top to roof-top, J. Hazard. Mater. 235-236 (2012) 29-46.

[7] M. Berney, H.U. Weilenmann, A. Simonetti, T. Egli, Efficacy of solar disinfection of Escherichia coli, Shigella flexneri, Salmonella Typhimurium and Vibrio cholerae, J. Appl. Microbiol. 101 (2006) 828-836.

[8] P. Fernández-Ibáñez, C. Sichel, M. Polo-López, M. de Cara-García, J. Tello, Photocatalytic disinfection of natural well water contaminated by Fusarium solani using $\mathrm{TiO}_{2}$ slurry in solar CPC photo-reactors, Catal. Today 144 (2009) 62-68.

[9] M. Polo-López, P. Fernández-Ibáñez, E. Ubomba-Jaswa, C. Navntoft, I. GarcíaFernández, P. Dunlop, M. Schmid, J. Byrne, K.G. McGuigan, Elimination of water pathogens with solar radiation using an automated sequential batch CPC reactor, J. Hazard. Mater. 196 (2011) 16-21.

[10] J. Ndounla, D. Spuhler, S. Kenfack, J. Wéthé, C. Pulgarin, Inactivation by solar photo-Fenton in pet bottles of wild enteric bacteria of natural well water: absence of re-growth after one week of subsequent storage, Appl. Catal. B 129 (2013) 309-317.

[11] F. Bichai, M.I. Polo-López, P. Fernández Ibañez, Solar disinfection of wastewater to reduce contamination of lettuce crops by Escherichia coli in reclaimed water irrigation, Water Res. 46 (2012) 6040-6050.
[12] E. Ortega-Gómez, B. Esteban García, M.M. Ballesteros Martín, P. Fernández Ibáñez, J.A. Sánchez Pérez, Inactivation of Enterococcus faecalis in simulated wastewater treatment plant effluent by solar photo-Fenton at initial neutral pH, Catal. Today 209 (2013) 195-200.

[13] S. Giannakis, A.I. Merino Gamo, E. Darakas, A. Escalas-Cañellas, C. Pulgarin, Impact of different light intermittence regimes on bacteria during simulated solar treatment of secondary effluent: implications of the inserted dark periods, Sol. Energy 98 (Part C) (2013) 572-581.

[14] L. Rizzo, D. Sannino, V. Vaiano, O. Sacco, A. Scarpa, D. Pietrogiacomi, Effect of solar simulated $\mathrm{N}$-doped $\mathrm{TiO} 2$ photocatalysis on the inactivation and antibiotic resistance of an E. coli strain in biologically treated urban wastewater, Appl. Catal. B 144 (2014) 369-378.

[15] O.K. Dalrymple, E. Stefanakos, M.A. Trotz, D.Y. Goswami, A review of the mechanisms and modeling of photocatalytic disinfection, Appl. Catal. B 98 (2010) 27-38.

[16] A. Geeraerd, C. Herremans, J. Van Impe, Structural model requirements to describe microbial inactivation during a mild heat treatment, Int. J. Food Microbiol. 59 (2000) 185-209.

[17] P. Mafart, O. Couvert, S. Gaillard, I. Leguérinel, On calculating sterility in thermal preservation methods: application of the Weibull frequency distribution model, Int. J. Food Microbiol. 72 (2002) 107-113.

[18] J. Marugán, R. van Grieken, C. Sordo, C. Cruz, Kinetics of the photocatalytic disinfection of Escherichia coli suspensions, Appl. Catal. B 82 (2008) 27-36.

[19] A.I. Gomes, J.C. Santos, V.J.P. Vilar, R.A.R. Boaventura, Inactivation of Bacteria E. coli and photodegradation of humic acids using natural sunlight, Appl. Catal. B 88 (2009) 283-291.

[20] J. Marugán, R. van Grieken, C. Pablos, C. Sordo, Analogies and differences between photocatalytic oxidation of chemicals and photocatalytic inactivation of microorganisms, Water Res. 44 (2010) 789-796.

[21] F.M. Salih, Formulation of a mathematical model to predict solar water disinfection, Water Res. 37 (2003) 3921-3927.

[22] C. Sichel, J. Tello, M. de Cara, P. Fernández-Ibáñez, Effect of UV solar intensity and dose on the photocatalytic disinfection of bacteria and fungi, Catal. Today 129 (2007) 152-160.

[23] A.-G. Rincón, C. Pulgarin, Field solar E. coli inactivation in the absence and presence of $\mathrm{TiO}_{2}$ : is UV solar dose an appropriate parameter for standardization of water solar disinfection?, Sol Energy 77 (2004) 635-648.

[24] S. Malato, P. Fernández-Ibáñez, M.I. Maldonado, J. Blanco, W. Gernjak, Decontamination and disinfection of water by solar photocatalysis: recent overview and trends, Catal. Today 147 (2009) 1-59.

[25] A.-G. Rincón, C. Pulgarin, Absence of E. coli regrowth after $\mathrm{Fe}^{3+}$ and $\mathrm{TiO}_{2}$ solar photoassisted disinfection of water in CPC solar photoreactor, Catal. Today 124 (2007) 204-214.

[26] E. Nebot Sanz, I. Salcedo Davila, J. Andrade Balao, J. Quiroga Alonso, Modelling of reactivation after UV disinfection: effect of UV-C dose on subsequent photoreactivation and dark repair, Water Res. 41 (2007) 3141-3151.

[27] R.P. Sinha, D.-P. Häder, UV-induced DNA damage and repair: a review, Photochem. Photobiol. Sci. 1 (2002) 225-236.

[28] M.I. Polo-López, I. García-Fernández, T. Velegraki, A. Katsoni, I. Oller, D. Mantzavinos, P. Fernández-Ibáñez, Mild solar photo-Fenton: an effective tool for the removal of Fusarium from simulated municipal effluents, Appl. Catal. B 111 (2012) 545-554.

[29] S. Giannakis, A.I. Merino Gamo, E. Darakas, A. Escalas-Cañellas, C. Pulgarin, Monitoring the post-irradiation E. coli survival patterns in environmental water matrices: implications in handling solar disinfected wastewater, Chem. Eng. J. 253 (2014) 366-376.

[30] M. Stocker, Y. Pachepsky, D. Shelton, Performance of Weibull and linear semilogarithmic models in simulating inactivation in waters, J. Environ. Qual. 43 (2014) 1559-1565.

[31] OECD Guidelines for Testing of Chemicals, Simulation Test-Aerobic Sewage Treatment 303A, 1999.

[32] S. Malato Rodriguez, J. Blanco Gálvez, M. Maldonado Rubio, P. Fernández Ibáñez, D. Alarcón Padilla, M. Collares Pereira, J. Farinha Mendes, J. Correia de Oliveira, Engineering of solar photocatalytic collectors, Sol. Energy 77 (2004) 513-524.

[33] A. Geeraerd, V. Valdramidis, J. Van Impe, GInaFiT, a freeware tool to assess non-log-linear microbial survivor curves, Int. J. Food Microbiol. 102 (2005) 95105.

[34] M.A.J.S. van Boekel, On the use of the Weibull model to describe thermal inactivation of microbial vegetative cells, Int. J. Food Microbiol. 74 (2002) 139159.

[35] L. Caballero, K. Whitehead, N. Allen, J. Verran, Inactivation of Escherichia coli on immobilized $\mathrm{TiO}_{2}$ using fluorescent light, J. Photochem. Photobiol. A 202 (2009) 92-98.

[36] M. Fabbricino, L. d'Antonio, Use of solar radiation for continuous water disinfection in isolated areas, Environ. Technol. 33 (2012) 539-544.

[37] W. Harm, Biological Effects of Ultraviolet Radiation, Cambridge University Press, Cambridge, 1980.

[38] M. Berney, H.-U. Weilenmann, T. Egli, Adaptation to UVA radiation of E. coli growing in continuous culture, J. Photochem. Photobiol. B 86 (2007) 149-159.

[39] A.F.F. Giacobone, O.J. Oppezzo, Survival of Pseudomonas aeruginosa exposed to sunlight resembles the phenom of persistence, J. Photochem. Photobiol. B 142 (2015) 232-236.

[40] J. Ndounla, S. Kenfack, J. Wéthé, C. Pulgarin, Relevant impact of irradiance (vs. dose) and evolution of $\mathrm{pH}$ and mineral nitrogen compounds during natural 
water disinfection by photo-Fenton in a solar CPC reactor, Appl. Catal. B 148149 (2014) 144-153.

[41] P.H. Quek, J. Hu, Indicators for photoreactivation and dark repair studies following ultraviolet disinfection, J. Ind. Microbiol. Biotechnol. 35 (2008) 533541.

[42] F. Bosshard, M. Bucheli, Y. Meur, T. Egli, The respiratory chain is the cell's Achilles' heel during UVA inactivation in Escherichia coli, Microbiology 156 (2010) 2006-2015.

[43] F. Bosshard, K. Riedel, T. Schneider, C. Geiser, M. Bucheli, T. Egli, Protein oxidation and aggregation in UVA-irradiated Escherichia coli cells as signs of accelerated cellular senescence, Environ. Microbiol. 12 (2010) 2931-2945.

[44] G. Zetterberg, Mutagenic effects of ultraviolet and visible light, in: A.G. Giese (Ed.), Photophysiology, vol. 2, Academic Press, New York, 1964, pp. 245-281.

[45] J.W. Martin, J.W. Chin, T. Nguyen, Reciprocity law experiments in polymeric photodegradation: a critical review, Prog. Org. Coat. 47 (2003) 292-311.
46] S. Giannakis, E. Darakas, A. Escalas-Cañellas, C. Pulgarin, Temperaturedependent change of light dose effects on $E$. coli inactivation during simulated solar treatment of secondary effluent, Chem. Eng. Sci. 126 (2015) $483-487$.

[47] H.J. Hoben, P. Somasegaran, Comparison of the pour, spread, and drop plate methods for enumeration of Rhizobium spp, inoculants made from presterilized peat, Appl. Environ. Microbiol. 44 (1982) 1246-1247.

48] A.-G. Rincón, C. Pulgarin, Bactericidal action of illuminated $\mathrm{TiO}_{2}$ on pure Escherichia coli and natural bacterial consortia: post-irradiation events in the dark and assessment of the effective disinfection time, Appl. Catal. B 49 (2004) 99-112.

499] S. Giannakis, E. Darakas, A. Escalas-Cañellas, C. Pulgarin, The antagonistic and synergistic effects of temperature during solar disinfection of synthetic secondary effluent, J. Photochem. Photobiol. A 280 (2014) 14-26. 